\title{
Subarctic Records and Range Extensions of Two Species of Tiger Beetles (Coleoptera: Cicindelidae) in Churchill and Wapusk National Park, Manitoba
}

\author{
Thomas S. Woodcock ${ }^{1}$, Peter G. Kevan ${ }^{1}$, and Robert E. Roughley ${ }^{2}$ \\ ${ }^{1}$ Department of Environmental Biology, University of Guelph, 50 Stone Rd. E., Guelph, Ontario, N1G 2W1 Canada \\ ${ }^{2}$ Department of Entomology, University of Manitoba, Winnipeg, Manitoba, R3T 2N2 Canada \\ Corresponding Author: Thomas Woodcock; e-mail: twoodcoc@uoguelph.ca
}
Woodcock, Thomas S., Peter G. Kevan, and Robert E. Roughley. 2010. Subarctic records and range extensions of two species of tiger beetles (Coleoptera: Cicindelidae) in Churchill and Wapusk National Park, Manitoba. Canadian Field-Naturalist 124(2): 118-121.

Two species of tiger beetle (Coleoptera: Cicindelidae) were collected in the vicinity of Churchill, Manitoba and Wapusk National Park. Habitats were dry, sandy areas typically preferred by this family. No tiger beetle has been recorded from this region previously. Cicindela longilabris longilabris was collected in two localities, one south of Churchill and another on a relict beach ridge in Wapusk National Park. Cicindela limbata hyperborea was collected only on the beach ridge, where adults co-occurred with $C$. longilabris longilabris. These localities represent significant range extensions for both species.

Key Words: Cicindela longilabris Say, Cicindela limbata Say, Wapusk National Park, beach ridge.

Tiger beetles (order Coleoptera, family Cicindelidae) are attractive, fast-moving, and conspicuous predators of invertebrates in open areas. Over 2000 species are known worldwide and approximately 111 in North America (Pearson and Cassola 1992; Pearson et al. 2005). Most species prefer dry habitats such as sand dunes, rocky outcrops or clay banks (Pearson et al. 2005). Some are known to withstand hypoxic conditions during periodic flooding of their habitat, particularly as larvae (Hoback et al. 1998; Brust and Hoback 2009). The larvae dwell in burrows in the same habitats as the adults, and are also voracious predators of smaller invertebrates. Their interesting biology and the beautiful iridescent colouration of adults make tiger beetles the subjects of a broad base of enthusiasts among professional and amateur naturalists alike, rivalled only by the devotees of Lepidoptera and Odonata. Although many species of tiger beetle are widely distributed, few records exist from northern areas of the world. In this paper, we report the collection of two species of tiger beetles in the Churchill region of northern Manitoba, Canada (Figure 1), an area from which they were previously unrecorded. Collecting insects in the north can be difficult, considering vagaries of weather, dangerous wildlife (polar bears), and remoteness. Sampling in Wapusk National Park requires extensive logistical support, including helicopter travel and bear security personnel, the latter being mandatory for researchers working with Parks Canada in the Churchill region.

The first record for $C$. longilabris longilabris southeast of the town of Churchill, along a sandy road atop the kame between Twin Lakes (15N 452807 UTM 6498079), came from the Arctic \& Boreal Entomology Course held in the Churchill region in 2004 (Taki et al.
2005). In 2009, C. longilabris longilabris (13.5-14 mm in length; Figure 2A) was taken along the same road on July 7 , and on a relict beach ridge in Wapusk National Park (15N 447959 UTM 6381822, Figure 3) on July 12. C. limbata hyperborea $(11 \mathrm{~mm}$ in length; Figure 2B) was also taken on the beach ridge, with adults of the two species active and coexisting in the same area. These records represent significant extensions of the known ranges for both of these species (Pearson et al. 2005). Specimens are deposited at the J. B. Wallis Museum, University of Manitoba.

Although most diverse in warm, dry climates, arctic and subarctic records of tiger beetles are not unknown. Cicindela longilabris has a typical boreal distribution, and is known to occur across North America from Newfoundland to northern Alaska, with its northern limit approximating the tree line (Schultz et al. 1992; Pearson et al. 2005). Cicindela limbata has several recognized subspecies, formerly including the critically endangered Coral Pink Sand Dunes tiger beetle (C. l. albissima) of Utah, which has been elevated to species status by Morgan et al. (2000). Several subspecies occur in northern regions of North America, most commonly on sand dune formations, including the recently described C. l. nogahabarensis from an area of sand dunes in Alaska (Knisely et al. 2008), possibly including the Kobuk Sand Dunes (Kobuk Valley National Park) in western Alaska, north of the Arctic Circle (Pearson et al. 2005). Cicindela oregona guttifera has also been recorded north of the Arctic Circle in Alaska (Brzoska 2008).

There are two subspecies of $C$. limbata found in Manitoba; $C$. limbata limbata extends into the southwestern part of Manitoba, but $C$. limbata hyperborea is recorded from the extreme northwest of the province 

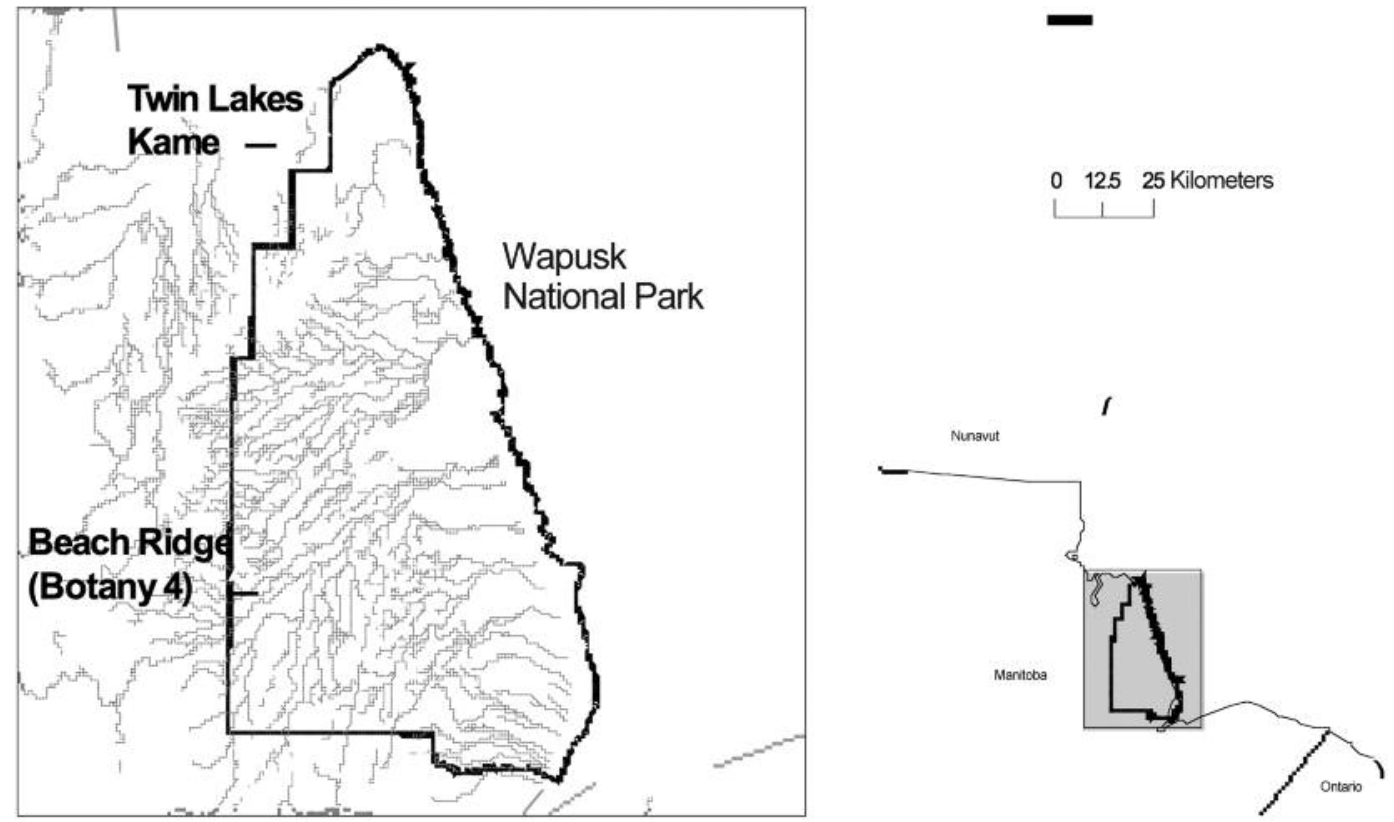

FIGURE 1. Map of the Churchill region and Wapusk National Park, including collection locations of Cicindela longilabris longilabris and $C$. limbata hyperborea.
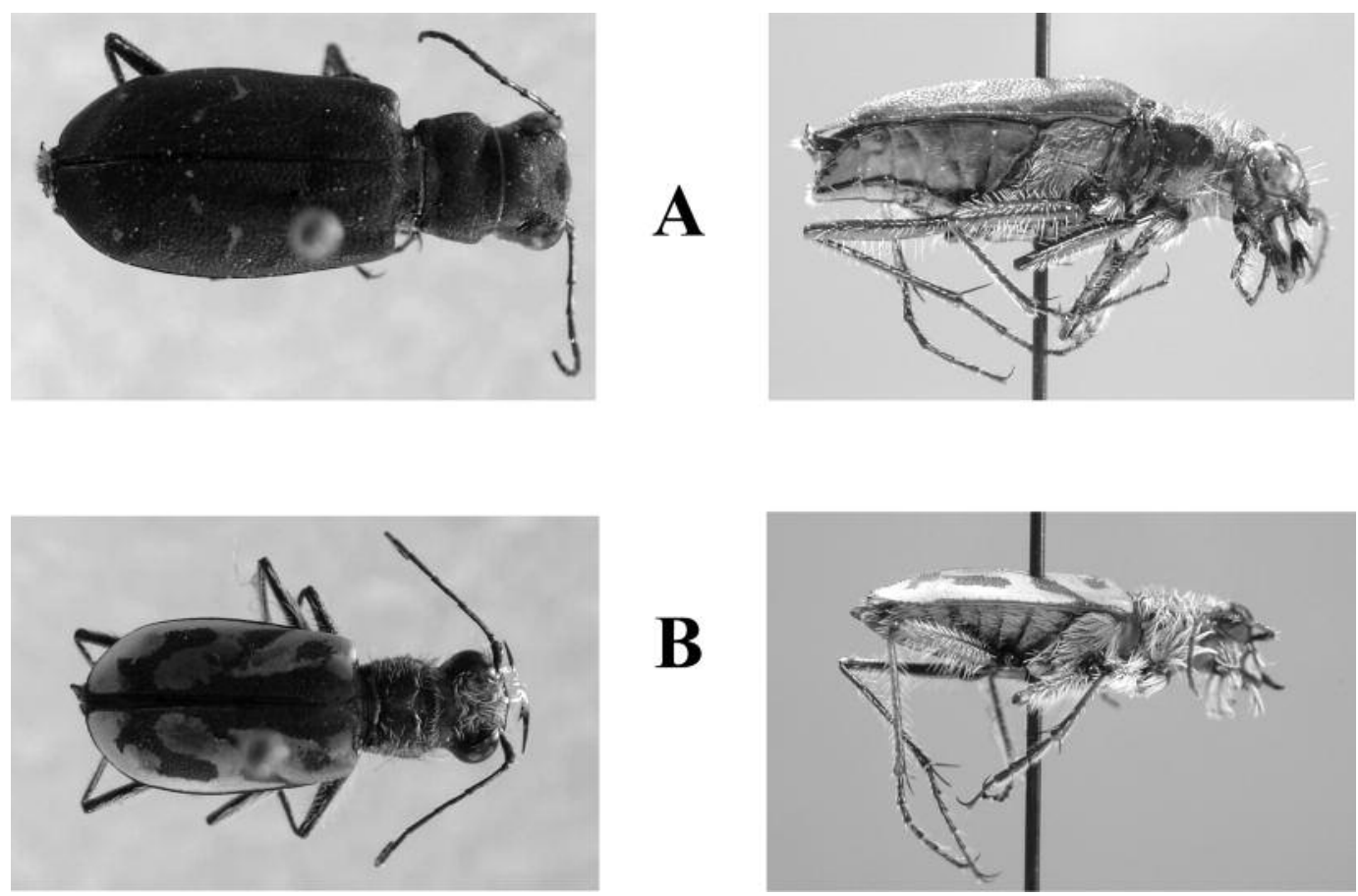

FIGURE 2. Dorsal (left) and lateral (right) views of pinned specimens of Cicindela longilabris longilabris (A) and C. limbata hyperborea (B) collected in the Churchill region. 


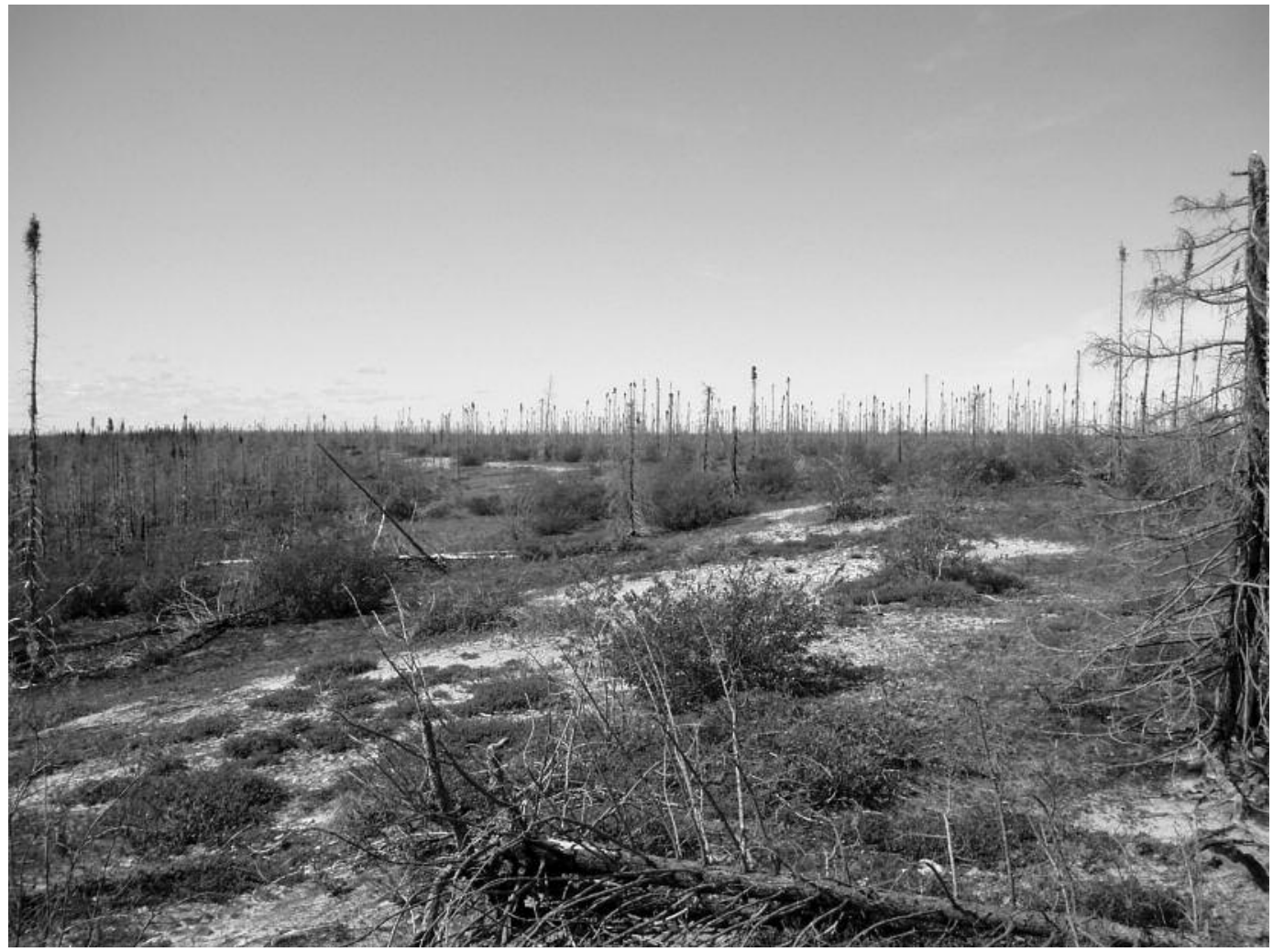

FIGURE 3. A relict beach ridge in Wapusk National Park supporting populations of both Cicindela longilabris longilabris and C. limbata hyperborea.

(Pearson et al. 2005). The latter subspecies was also reported from Goose Bay, Labrador and has been thought to have been introduced to the area by human activity (Larson 1986; Pearson et al. 2005). However, this population has now been assigned to a new subspecies (C. l. labradorensis), and is suspected to be a remnant of a broader distribution of $C$. limbata that colonized the area following the glacial retreat (Johnson 1989; Brzoska and Stamatov 2008).

Many tiger beetles are known to be active at high temperatures (Pearson et al. 2005), and their adaptation to thermoregulate effectively by solar basking under such conditions could be a factor in the southerly distribution of most species. Schultz et al. (1992) found that adult $C$. longilabris from populations in different parts of their range were capable of activity at lower temperatures than many species, and may occupy cooler habitats than other species at lower latitudes. Although adults are active only during the summer season, overwintering larvae or pupae require adaptations including tolerance to being frozen. These larvae may take up to three years to reach adulthood in Manitoba (Hamilton 1925). Adults may also need to cope with cold in the summer season. Adults' adapta- tions may include dark colouration (melanism), as seen in C. longilabris longilabris (Figure 2A) and/or hairiness as in C. limbata hyperborea (Figure 2B). Several groups of arctic insects, including bumble bees and certain Lepidoptera, have been shown to use dense hairs to conserve metabolic heat and reduce convective heat loss, a strategy that may be particularly effective in concert with melanism (Downes 1965; Danks 2004) and behavioural thermoregulation (Kevan 1989).

\section{Acknowledgments}

The authors thank Parks Canada, particularly S. Kowalchuk, J. Larkin, and M. Ratson, for logistical support and field assistance during our collecting efforts in Wapusk National Park. This work was funded in part by an NSERC International Polar Year research grant.

\section{Literature Cited}

Brust, M. L., and W. W. Hoback. 2009. Hypoxia tolerance in adult and larval Cicindela tiger beetles varies by life history but not habitat association. Annals of the Entomological Society of America 102: 462-466.

Brzoska, D. W. 2008. Note on tiger beetles above the Arctic Circle. Cicindela 40: 65-66. 
Brzoska, D. W., and J. Stamatov. 2008. A trip to Goose Bay, Labrador, Canada. Cicindela 40: 47-52.

Danks, H. V. 2004. Seasonal adaptations in Arctic insects. Integrative and Comparative Biology 44: 85-94.

Downes, J. A. 1965. Adaptations of insects in the Arctic. Annual Review of Entomology 10: 257-274.

Hamilton C. C. 1925. Studies on the morphology, taxonomy and ecology of the larvae of Holarctic tiger beetles (family Cicindelidae). Proceedings of the United States National Museum 65, Article 17: 1-87.

Hoback, W. W., D, W. Stanley, L. G. Higley, and M. C. Barnhart. 1998. Survival of immersion and anoxia by larval tiger beetles, Cicindela togata. American Midland Naturalist 140: 27-33.

Johnson, W. N. 1989. A new subspecies of Cicindela limbata Say from Labrador, Canada (Coleoptera, Cicindelidae). Naturaliste Canadien 116: 261-266.

Kevan, P. G. 1989. Thermoregulation in arctic insects and flowers: Adaptation had co-adaptation in behaviour, anatomy, and physiology. Pages 747-754 in Thermal Physiology 1989. Edited by J. B. Mercer. Proceedings of the International Symposium on Thermal Physiology, Troms $\emptyset$, Norway, 16-21 July 1989. Excerpta Medica, Elsevier Science Publishers B.V. The Netherlands.

Knisely, C. B., M. R. Woodcock, and A. P. Vogler. 2008. A new subspecies of Cicindela limbata (Coleoptera: Cicindelidae) from Alaska, and further review of the maritima group by using mitochondrial DNA analysis. Annals of the Entomological Society of America 101: 277-288.

Larson, D. J. 1986. The tiger beetle Cicindela limbata hyperborea in Goose Bay, Labrador, Canada (Coleoptera, Cicindelidae). Coleopterists Bulletin 40: 249-250.

Morgan, M., C. B. Knisely, and A. P. Vogler. 2000. New taxonomic status of the endangered tiger beetle Cicindela limbata albissima (Coleoptera: Cicindelidae): Evidence from mtDNA. Annals of the Entomological Society of America 93: 1108-1115.

Pearson, D. L., and F. Cassola. 1992. World-wide species richness patterns of tiger beetles (Coleoptera: Cicindelidae): Indicator taxon for biodiversity and conservation studies. Conservation Biology 6: 376-391.

Pearson, D. L., C. Knisely, and C. J. Kazilek. 2005. A Field Guide to the Tiger Beetles of the United States and Canada. Oxford University Press, New York.

Schultz, T. D., M. C. Quinlan, and N. F. Hadley. 1992. Preferred body temperature, metabolic physiology, and body temperature of adult Cicindela longilabris - a comparison of populations from boreal habitats and climatic refugia. Physiological Zoology 65: 226-242.

Taki, H., P. G. Kevan, and R. E. Roughley. 2005. Arctic and boreal entomology course 2004. Bulletin of the Entomological Society of Canada 37: 156-158.

Received 17 October 2009

Accepted 12 April 2010 


\section{Errata for The Canadian Field-Naturalist 124(1) and 124(2)}

\section{Erratum 124(1): 97}

The January-March 2010, Volume 124, Number 1 issue of The Canadian Field-Naturalist. In a brief notice on page 97, News and Comment, re Hue MacKenzie's death; the death date is incorrect. It should be 9 November 2009, not December. Also, the retirement location is given as "... South Surry, Vancouver, British Columbia..." It should read "Surrey, British Columbia..." perhaps with some reference to Surrey being a suburb of Vancouver. The location as shown in the death notice doesn't exist.

Jo Ann MacKenZIE

\section{Erratum 124(2): 113, 115, 117}

In authors' line on 113 the last author "Powers" should be "Power". The error is repeated in the citation strip on the same page and in the headers on subsequent uneven numbered pages $(115,117)$.

\section{Erratum 124(2): 119, 121}

In headers on pages 119 and 121 "Keven" should be "Kevan".

\section{Erratum 124(2): 196}

In notice of Brenda Carter's death, the date of Tom Manning's passing should be 1998 not 1968.

DAN BRUNTON

\section{Erratum 124(2): 141}

Corrected table for paper by Dawson et al. on Wolverine

\section{Erratum 124(2): 102}

Corrected map in lead paper by Gilhen

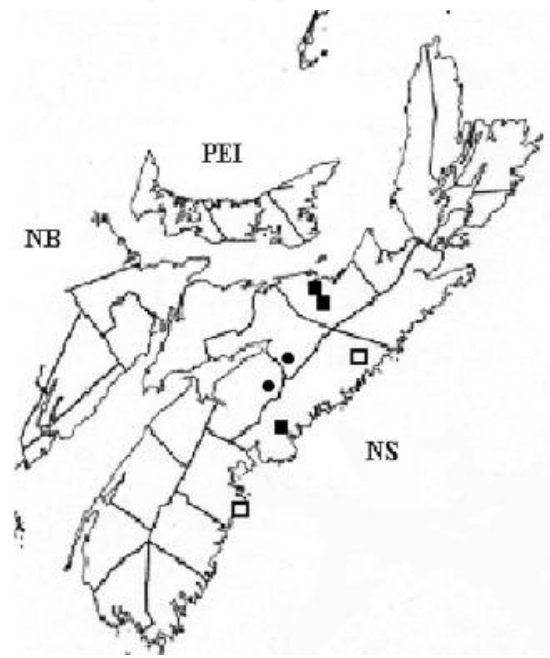

FIGURE 3. Distribution of erythristic Maritime Garter Snakes (Thamnophis sirtalis pallidulus), in Nova Scotia: Closed circles represent localities where two erythristic adult females were captured. Closed squares represent localities where part-erythristic individuals were captured. Open squares represent localities where only the dorsal colour patterns of two part-erythristic individuals were documented.

TABLE 1. Home range size (HR) based on minimum convex polygons (MCP) derived from all VHF radio telemetry locations for the period 25 February - 8 April 2004 for radio-collared Wolverines (Gulo gulo) in northwestern Ontario, Canada.

\begin{tabular}{|c|c|c|c|c|c|c|}
\hline Animal & $\begin{array}{l}\text { Estimated } \\
\text { Age (yrs) }\end{array}$ & $\begin{array}{c}\text { Number of Days } \\
\text { Located }\end{array}$ & $\mathrm{N}$ & $\begin{array}{l}100 \% \\
\mathrm{MCP}\end{array}$ & $\begin{array}{l}95 \% \\
\text { MCP }\end{array}$ & $\begin{array}{l}50 \% \\
\mathrm{MCP}\end{array}$ \\
\hline F01 & 1 & 30 & 33 & 316 & 235 & 41 \\
\hline $\mathrm{F} 02^{1}$ & 1 & 0 & 0 & - & - & - \\
\hline F03 & 1 & 24 & 27 & 495 & 453 & 38 \\
\hline F04 & $3+$ & 14 & 29 & 348 & 332 & 3 \\
\hline Mean & & & & 386 & 340 & 27 \\
\hline (SE) & & & & (55) & (63) & (12) \\
\hline M01 & 2 & 29 & 39 & 1898 & 1434 & 247 \\
\hline M02 & 1 & 13 & 15 & 2509 & $2509^{2}$ & 182 \\
\hline M03 & $3-4$ & 29 & 40 & 1685 & 1308 & 209 \\
\hline Mean & & & & 1791 & 1371 & 228 \\
\hline$(\mathrm{SE})$ & & & & (106) & (63) & (19) \\
\hline
\end{tabular}

${ }^{1}$ F02 was killed prior to the VHF monitoring period.

${ }^{2}$ Due to the low number of locations for this animal analysis results for $95 \mathrm{MCP}$ was the same as for $100 \mathrm{MCP}$ and all results for M02 are not included in the mean HR calculations 